Mongolian Academy of Sciences
Mongolian Journal of Chemistry
Institute of Chemistry \& Chemical Technology

\title{
Utilization of spent brewer's yeast Saccharomyces cerevisiae for the production of yeast enzymatic hydrolysate
}

\author{
M.Bayarjargal $^{1}$, E.Munkhbat ${ }^{1}$, T.Ariunsaikhan ${ }^{1}$, M.Odonchimeg ${ }^{1}$, \\ T.Uurzaikh $^{2}$, T.Gan-Erdene ${ }^{1}$, D.Regdel $^{3}$ \\ ${ }^{1}$ Institute of Chemistry and Chemical Technology, Mongolian Academy of Sciences \\ ${ }^{2}$ Mongolian National University \\ ${ }^{3}$ Mongolian Academy of Sciences
}

\begin{abstract}
Spent brewer's yeast (Saccharomyces cerevisiae) is a rich source of protein, vitamins and widely used as a raw material for production of food supplements. The autolysis and enzymatic treatment of spent brewer's yeast using Pancreatin (2.5\%) and Flavourzyme (2.5\%) were performed at $45{ }^{\circ} \mathrm{C}$ and $50{ }^{\circ} \mathrm{C}$, respectively. The autolysis and hydrolysis processes were evaluated by determining a soluble solids, soluble protein concentration and $\alpha$-amino nitrogen content in a reaction mixture. The yield of pancreatic digest and $\alpha$-amino nitrogen content was high in comparison with autolysis and Flavourzyme treatment. The total solids recovery in dry Yeast hydrolysate was about $50 \%$, a protein and $\alpha$-amino nitrogen content was 55.9 and $4.8 \%$, respectively. These results show the possibility of utilizing the spent brewer's yeast as hydrolysate using hydrolytic enzymes and use it as a food supplement after biological experiments.
\end{abstract}

Keywords: spent brewer's yeast Saccharomyces cerevisiae, enzymatic hydrolysis, Pancreatin, Flavourzyme

\section{Introduction}

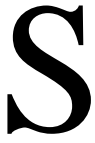
accharomyces cerevisiae yeast species are most extensively used in brewery industry and leaven bread dough $[1,2]$. They are also a source for the production of Yeast extracts comprising the water soluble components of the yeast cell, the composition of which is primarily amino acids, peptides, carbohydrates and salts. Yeast extracts are used widely in food with two main purposes, i.e., to improve the flavor of food to satisfy consumer and to increase the nutritional value [3]. Yeast extracts used as ingredients in food industry for production of soups, gravies and meat products as well as in cosmetic materials, animal feed, microbiological growth media. Other applications include protein and vitamin supplements in health and functional food.

There are 3 main methods for the production of Yeast extract: autolysis, plasmolysis and hydrolysis [4]. Autolysis of the yeast is a degradation process carried out by activating the yeast's own cell enzymes to disruption of cell components. Although autolysis is a traditional manufacturing process in the yeast extract production there are some disadvantages: low yield, difficulty in solid-liquid separation, poor taste characteristics as a flavor enhancer and risk of deterioration due to microbial contamination.

Plasmolysis is a modified autolysis process in the presence of so-called accelerators, such as an inorganic salt 
(sodium chloride) or organic solvent (toluene, ethanol, ethyl acetate).

Hydrolysis which is performed by acids or enzymes is the most efficient method for solubilizing the yeast. Despite a high production yield, acid hydrolysis is less attractive because of the relatively high capital investment cost, high salt content and high probability of containing carcinogenic compounds [5].

Enzymatic hydrolysis of yeast is carried out by enzyme preparations of bacterial, vegetable, yeast, or animal origins, such as Flavourzyme, Lyticase, Papain, Pepsin and Pancreatin. Enzymatic hydrolysis of proteinaceous materials is a mild process compared to acid hydrolysis leading to peptides with various range of biological activities. Some peptides with high levels of radical scavenging activities, oral glucose tolerance activity and ACE inhibitory effect have been revealed in the enzymatic hydrolysis of yeast substances $[6,7]$

Therefore, the objective of this study was to examine the utilisation of spent brewer's yeast Saccharomyces cerevisiae for production of enzymatic hydrolysate using Flavourzyme and Pancreatin as enzyme source.

\section{Experimental}

Materials. The spent brewer's yeast Sacch. cerevisiae used as a substrate was donated by "APU" company. The suspension of yeast was washed with cold water 3 times for debittering and removing beer solids. Filtrated yeast slurry was frozen before running the hydrolysis process. Two types of enzyme were used in the yeast hydrolysis: Flavourzyme (Novozymes, Denmark) from Asp. Oryzae and Pancreatin (Serva, Germany) from the hog pancreas.

Autolysis process. The spent brewer's yeast suspensions $(18 \% \mathrm{w} / \mathrm{w})$ were placed in glass vessels immersed in a temperature controlled water bath. The autolysis was carried out at 45 and $50{ }^{\circ} \mathrm{C}$ for 30 hours under agitation. For determination of the solids, protein and $\alpha$ amino nitrogen concentration the autolysis mixture was heated in a boiling water bath for $5 \mathrm{~min}$ and centrifuged (4000 rpm) for $10 \mathrm{~min}$.
Enzymatic hydrolysis. The spent brewer's yeast slurry was suspended in water to achieve a concentration of $10 \%(\mathrm{w} / \mathrm{v})$. The yeast suspensions were placed in glass vessels immersed in a temperature controlled water bath with mechanical stirrer. The hydrolysis was performed at $45{ }^{\circ} \mathrm{C}$ and $50{ }^{\circ} \mathrm{C}$. The initial $\mathrm{pH}$ was adjusted to 6.0 and 8.0 with $\mathrm{NaOH}$ solution for Flavourzyme and Pancreatin hydrolysis respectively. Flavourzyme or Pancreatin at $2.5 \%$ concentration was added and the hydrolysis process was allowed for 5 hours. After all the enzymatic treatments the sample was inactivated (boiling water bath, 5 min) and centrifuged.

Analytical methods. The total solids of the yeast slurry or suspensions were determined by dry weights, following drying at $105{ }^{\circ} \mathrm{C}$ until constant mass was achieved [8]. The soluble solids of the autolysis and hydrolysis solution were measured using a refractometer [8]. The soluble protein content was determined by the Biuret method [9]. The total nitrogen content was measured by the Kjeldahl method and total protein was calculated via multiplication of total nitrogen by 6.25 [10]. $\alpha$-Amino nitrogen $\left(\mathrm{N}_{\mathrm{amin}}\right)$ was measured by TNBS reaction using glycine as a standard [11].

\section{Results and Discussion \\ Results}

The influence of temperature on soluble solids content and soluble protein concentration during autolysis of spent brewer's yeast is given in Fig. 1 and 2, respectively. The release of solids and protein into the autolysis media are increased with increasing incubation time.

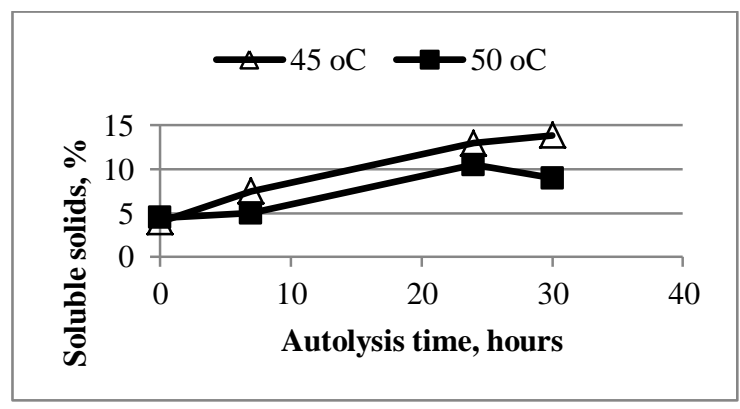

Fig. 1. The soluble solids content of Yeast extract during autolysis 


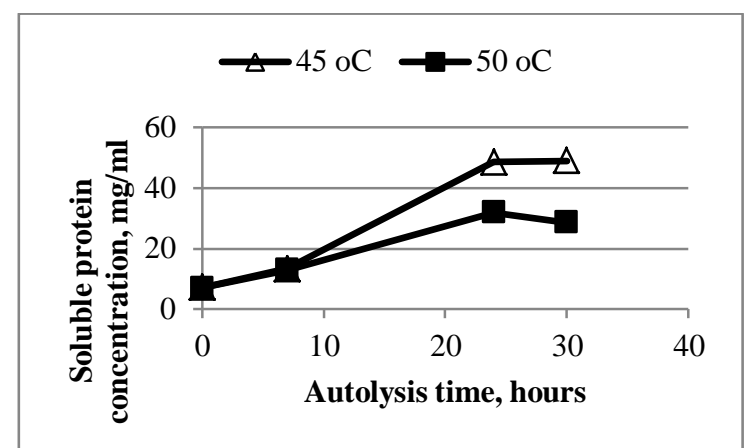

Fig. 2. The soluble protein content of Yeast extract during autolysis

After 30 hours of brewer's yeast autolysis the soluble solids content in media at 45 and $50{ }^{\circ} \mathrm{C}$ was 13.7 and $10.1 \%$, respectively. At the end time of autolysis at $45{ }^{\circ} \mathrm{C}$ the soluble protein concentration was reached $49 \mathrm{mg} / \mathrm{ml}$, which is 1.7 times higher than the soluble protein content at $50{ }^{\circ} \mathrm{C}$.

The highest yield of $\alpha$-amino nitrogen was obtained at $45{ }^{\circ} \mathrm{C}$ which was twice higher than compared with autolysis product obtained at $50{ }^{0} \mathrm{C}$. The results are illustrated in Fig. 3.

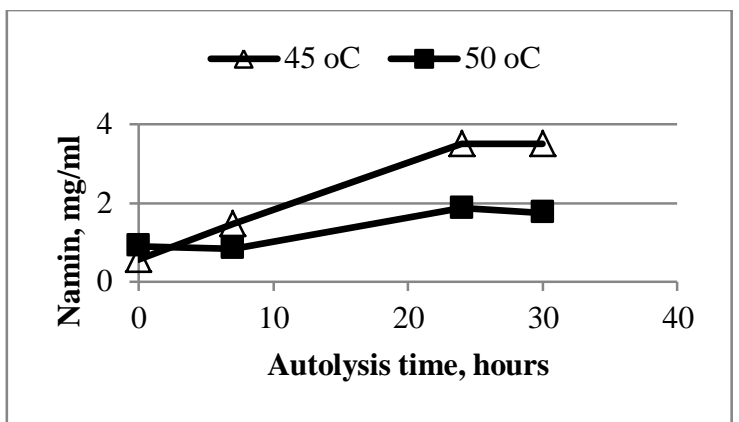

Fig. 3. The $\alpha$-amino nitrogen content of Yeast extract during autolysis

Along with the purpose for enhancing the yield of Yeast extract the enzymatic hydrolysis of the spent brewer's yeast using Flavourzyme and Pancreatin was carried out. The release of soluble solids and increase of the soluble protein content in hydrolysates are illustrated in Fig. 4 and 5 respectively.

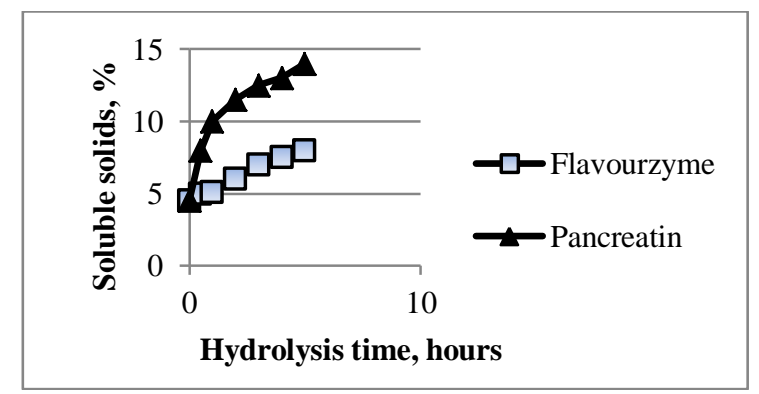

Fig. 4. The soluble solids content of Yeast hydrolysate

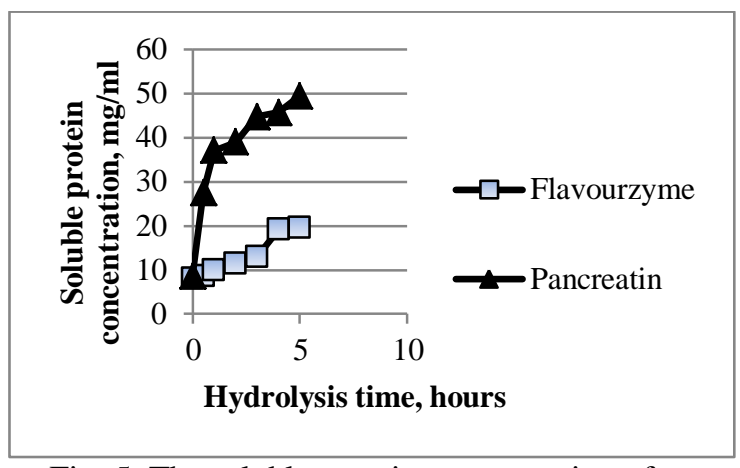

Fig. 5. The soluble protein concentration of yeast hydrolysate

During the enzymatic hydrolysis the release of soluble solids and protein was more effective. Released soluble solids and protein were higher than those obtained by the autolysis process for equal time. Pancreatin (2.5\%) application was more effective therefore, the pancreatic

hydrolysis performed more extensive than Flavourzyme (2.5\%) hydrolysis.

Pancreatin treatment led to $14 \%$ content of soluble solids and $49.5 \mathrm{mg} / \mathrm{ml}$ soluble protein concentration in hydrolysis media only within 5 hours.

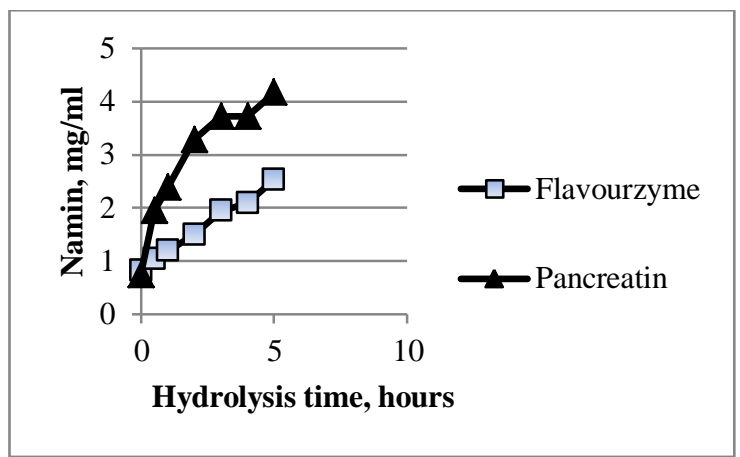

Fig. 6. The $\alpha$-amino nitrogen content of Yeast hydrolysate

The $\alpha$-amino nitrogen content in pancreatic hydrolysis media was 1.2 times higher than in final autolysis products.

\section{Discussion}

The autolysis of Baker's yeast Saccharomyces cerevisiae occurs around a $\mathrm{pH}$ of 5.0 at $45-50{ }^{\circ} \mathrm{C}[1,12]$. Yield of solids is an important economic parameter in the production of yeast extract, thus we used above mentioned conditions for the comparison of the yield of spent brewer's yeast extract obtained by autolysis process and enzymatic hydrolysis using two enzyme 
preparations with different $\mathrm{pH}$ optimum and species.

In this study the temperature influenced on the solids content of Yeast extracts. The yield of final products (soluble solids and protein concentration) at $45^{\circ} \mathrm{C}$ was higher than at $50{ }^{\circ} \mathrm{C}$ in the autolysis as well as in the hydrolysis by Pancreatin. High concentration of final products obtained by Pancreatin treatment may be explained as the result of synergic action of yeast intracellular enzymes and pancreatic enzyme complex including proteases with different specificities. The yield of pancreatic hydrolysate from spent brewer's yeast in our study was about $50 \%$ which is in the range of reported level 41.0-61.3\% [12, 13].

The relatively small yield of Flavourzyme hydrolysate in our study could also be partially related to exoprotease specificity of this preparation. High solid recovery (48.3-53.1\%) was obtained when the yeast cells were treated using endoprotease and exoprotease mixture $(0.6 \%$ Protamex and $0.6 \%$ Flavourzyme) [13].

The protein content of obtained Yeast extract in the form of pancreatic hydrolysate after drying was $55.9 \%(\mathrm{~N} \times 6.25), \alpha$-amino nitrogen content $-4.8 \%$, ash $-4.2 \%$. These values correspond to the chemical characteristics of dry yeast extract from MPBio company /Cat. No. 103304/.

\section{Conclusions}

In the present study the effect of autolysis and enzymatic treatment of spent brewer's yeast was examined. Enzymatic treatment leads to the high recovery of the total solids in preparation of Yeast extract. We anticipate that Pancreatin is more optimal enzyme source than Flavourzyme for hydrolysis of yeast slurry at $45^{\circ} \mathrm{C}$.

\section{References}

1. Tanguler H., Erten H. (2008). Food Bioprocessing. 86, 317-321.

2. Sommer R. (1998). Food Australia, 50 (4), 181-183.

3. Boonraeng S., Foo-trakul P., Kanlayakrit W., Chetanachitra C. (2000). Kasetsart J. (Nat. Sci.), 34, 270-278.

4. Milic T.V., Rakin M., SilerMarinkovic S. (2007). J. Serb. Chem. Soc. 72 (5), 451-457.

5. Nagowithana T. (1992). Food Technol. 46, 138.

6. Jung E.Y., Lee H.S. Choi J.W., Ra K.S., Kim M.R., Suh H.J. (2011). J.Food Sci. 76 (2), 272-278.

7. Kanauchi O., Igarashi K., Ogata R., Mitsuyama K., Andoh A. (2005). Curr. Med. Chem. 12 (26), 3085-3090.

8. Ермаков А.И., Арасимович В.Е., Смирнова-Иконникова М.И., Ярош Н.П., Луковникова Г.А. (1972). Методы биохимического исследования растений. Л.: Колос, $456 \mathrm{c}$.

9. Layne E. (1957). Methods in Enzymology, 10, 447-455.

10. AOAC (1990). Official methods of analysis. Association of Official Analytical Chemists. K.Hekrich, $15^{\text {th }}$ ed., Arington, Virginia

11. Freitas O., Padovan G.J., Vilela L., Dos Santos J.E., Oliveira J.E.D., Greene L.J. (1993). J. Agric. Food Chem., 41 (9), 1432-1438

12. Behalova B., Beran K. (1986). Acta Biotechnol. 6, 147-152.

13. Chae H.J., Joo H. (2001), Bioresour. Technol., 76, 253-258. 